\title{
The Role of Monetary Policy in Dealing With Inflation and High Interest Rates
}

\author{
Statement of DARRYL R. FRANCIS, President, Federal \\ Reserve Bank of St. Louis, Before the Committee on \\ Banking and Currency, House of Representatives, July 18, 1974
}

Mr. Chairman and Members of the Committee:

I am pleased to have this opportunity to present my views regarding our country's inflation and high interest rates and the role of monetary policy in dealing with these and other economic problems.

My position regarding the cause of inflation and high market interest rates is that they both stem from the same source - an excessive trend rate of expansion of the nation's money stock. Monetary policy, therefore, can contribute to solving both of these problems over a period of a few years by fostering a non-inflationary rate of growth of the money supply.

I believe that the historically rapid rate of money growth of the past few years has caused an excessive rate of expansion of total spending in the economy. Since rapid money growth has stimulated a growth in demand for goods and services at rates much faster than our ability to produce, inflation has resulted.

The relationship between expansion of the money stock and the rate of inflation is illustrated in Chart $\mathrm{I}$. The money stock, defined as demand deposits and currency held by the nonbank public, increased slowly from early 1952 to late 1962 . Since then, the average rate of money growth has persistently accelerated. As indicated in Chart I, the general price index, measured by the GNP deflator, has risen, with a few quarters lag, at rates similar to growth of the money stock (except during Phases $I$ and $I I$ of the price and wage controls when reported prices were artificially held down).

High and rising market rates of interest go handin-hand with a high and accelerating rate of inflation. This is because lenders and borrowers of funds take into consideration their expectations with reference to the future rate of inflation. Lenders desire a market rate of interest which provides them a real rate of re- turn plus a premium based on their expectations regarding the future rate of inflation. Also, during inflation borrowers are willing to pay a higher market rate of interest because they expect the prices of their products to rise, and they wish to avoid the higher construction and other costs associated with delaying new projects. Thus, the interaction of demand and supply in the market for funds during a period of inflation results in market interest rates which embody an inflation premium.

This response of interest rates to inflation is illustrated in Chart I. During the period of a slowly rising general price level in the $1950 \mathrm{~s}$ and early $1960 \mathrm{~s}$, the seasoned corporate Aaa bond rate rose slowly until 1959 and subsequently remained little changed through 1965. Then, with accelerating inflation, this average of highest quality long-term market interest rates rose steadily for five years. It was relatively stable in 1971 and 1972, probably reflecting expectations of less rapid inflation as a result of Phases I and II of the price and wage control program. During that period the reported rate of inflation decreased to less than 3 percent. However, the renewed acceleration of inflation since early 1973 has been accompanied by a gradual, but marked, increase in the corporate Aaa bond rate.

According to my view of the relationships which run from an increase in the trend growth of money, to a higher rate of inflation, to higher market rates of interest, present high interest rates do not indicate restrictive monetary actions. On the contrary, they are the result of excessively expansionary monetary actions since the early 1960 s.

A natural question to be asked at this point is, "What has caused the observed trend growth of money?" My view is that growth of the monetary base is the prime determinant of growth of the money 


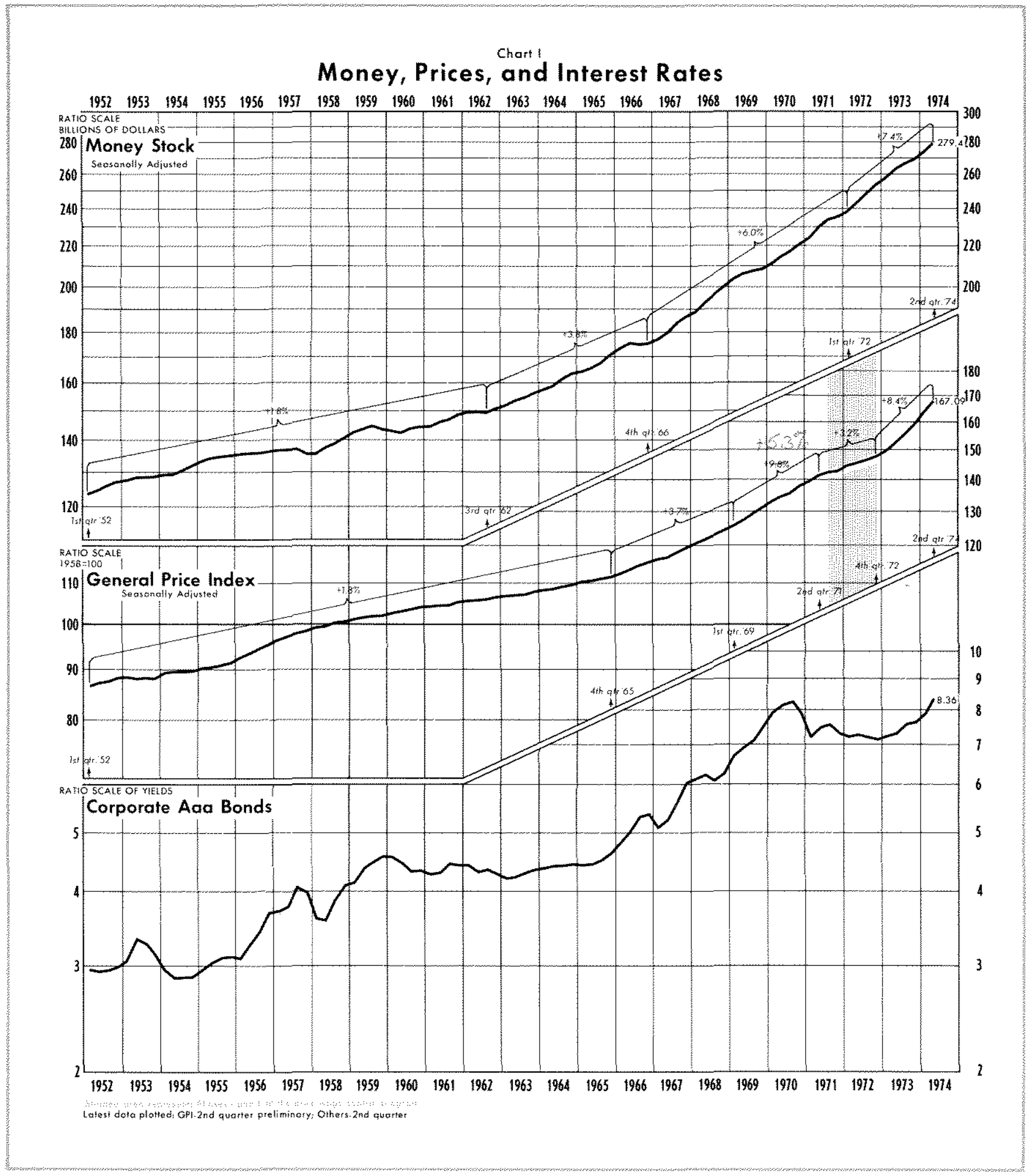

stock. The major sources of growth in the base are changes in the volume of Federal Government debt purchased by the Federal Reserve System on the open market, and occasional changes in the quantity or price of gold held by the Treasury. A change in the monetary base changes the amount of reserves in the banking system, which changes the amount of deposits created by commercial banks. 
Movements in the narrowly defined money stock over extended periods of time are closely associated with movements in the monetary base. Tiers 4 and 5 of Chart II illustrate this very close relationship, while the top three tiers show the relation between growth of the outstanding Federal Government debt and that portion held by the Federal Reserve System.

In my opinion, the actions that led to the acceleration in growth of the monetary base and money supply since the early 1960s occurred as a result of: (1) excessive preoccupation with the prevailing level of market interest rates; (2) the occurrence of large deficits in the Federal Government budget; and (3) shifting emphasis of policy actions because of an apparent short-run trade-off between inflation and unemployment.

Some people believe that the Federal Reserve System has a high degree of control over market interest rates. They argue that System open market purchases and sales of Government securities should be so conducted as to assure that unduly high market interest rates do not choke-off growth of output and employment. Throughout most of the $1960 \mathrm{~s}$, and to some extent in the $1970 \mathrm{~s}$, the published Record of Policy Actions of the Federal Open Market Committee indicates that the conduct of open market transactions was influenced, in considerable measure, by these two propositions. Once accelerating inflation started in the mid-1960s, and market interest rates began to rise reflecting an inflation premium, the System purchased Government securities in increasing quantities in an attempt to hold interest rates at the then prevailing levels. Such purchases resulted in rapid growth in both the monetary base and the money stock. In spite of the efforts to maintain a prevailing level, market interest rates continued to rise.

I accept neither the proposition that the Federal Reserve can control market interest rates nor that the high market interest rates have acted to choke-off economic expansion. Past experience, in my opinion, indicates quite conclusively that the Federal Reserve has little ability to control the level of market interest rates for any extended period of time. Experience also indicates, for both this and other countries, that growth of total spending has been retarded very little by high interest rates. On the other hand, attempts to resist upward movements in market interest rates have resulted in faster growth of money.

Another concern which has been expressed about market interest rates is that they should be controlled in order to prevent dislocations in the flows of funds to savings institutions, the housing industry, and state and local governments. In addition, there is a commonly-held view that small businesses, farmers, and the average consumer should not have to pay high interest rates when they borrow. The published policy Record indicates that the Federal Reserve responded to such concerns at various times over the past ten years, especially following the credit crunches of 1966 and 1969.70.

Good though the intentions may have been, I am convinced that monetary actions based on these views have been self-defeating. As explained earlier, such attempts to maintain nominal interest rates below their free market level in a period of inflationary upward pressure has resulted in accelerating money growth, an acceleration in inflation, and still higher interest rates. Thus, those presumed to be protected by such a course of monetary actions actually turn out to be worse off - they end up with both more inflation and higher interest rates.

Another concern regarding market interest rates relates to the Federal Reserve's role in the orderly marketing of U.S. Government debt. This refers to the so-called "even-keel" operations, which have had a long tradition in central banking. When new Government securities are issued, there is additional demand for credit and temporary upward pressure on market interest rates normally occurs. Since changes in interest rates traditionally have been viewed as interfering with the orderly process of marketing new issues, fluctuations of market rates during the financing period have been limited by purchases of securities on the open market which, in turn, add to the monetary base.

The published Record indicates that during much of the period of accelerating inflation System open market operations were constrained by "even-keel" considerations. Furthermore, System purchases of securities during even-keel periods were not fully offset by subsequent sales and, as a result, money growth accelerated.

This process, in effect, has resulted in at least partial financing of Government deficits through the creation of money rather than borrowing from the private sector. In many other countries the same result has occurred by the simple and direct expedient of the Government printing the money which is then spent on goods and services.

Since the direct method of printing money to finance Government expenditures is prohibited in the U.S., the monetization of Government deficits has oc- 
Influence of Federal Government Debt on Monetary Expansion

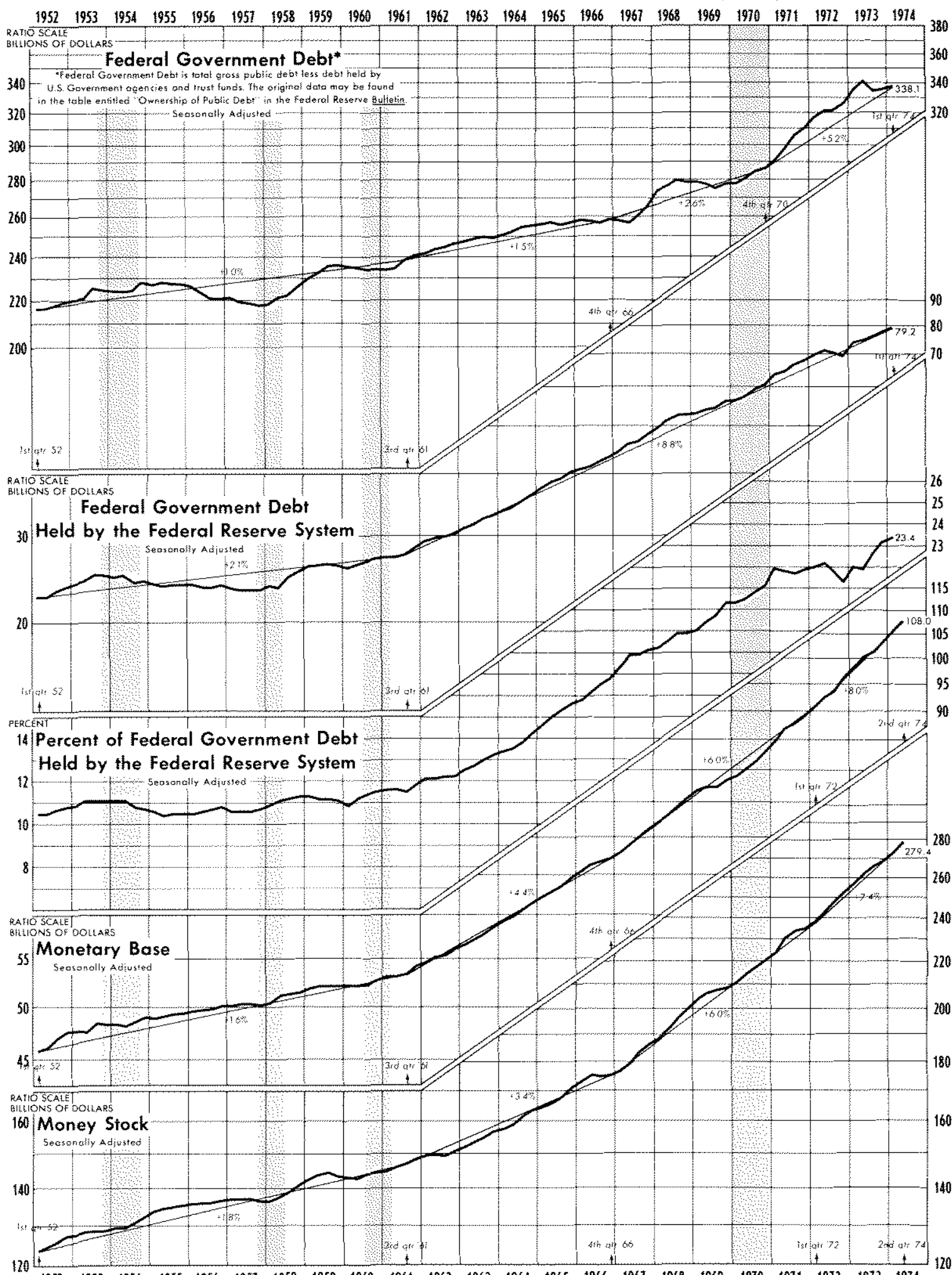

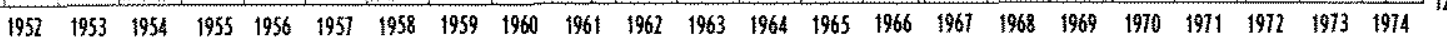

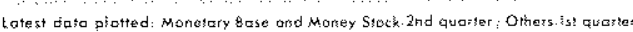


curred indirectly. Our deficit spending is always financed, at least initially, through the sale of new Govemment securities to the public. But when the Federal Reserve System buys outstanding securities from the public, a part of the Government debt is ultimately being financed by the creation of new money. This is because the Federal Reserve System pays for the securities purchased on the open market by creating a credit to member bank reserve accounts, which increases the monetary base and money held by the public.

Charts II and III illustrate the results of the process described above. The increases in Government debt and the amounts of debt that have been purchased by the public and the Federal Reserve System are shown in the first column of Chart III. The proportion of debt bought by the Federal Reserve has been increasing except for the 1971.72 period when substantial amounts were acquired by foreigners. The second column for each time period indicates that changes in the monetary base have closely paralleled Federal Reserve purchases of Government securities. It is this closeness that illustrates monetization of the Government debt. The resulting increases in the monetary base, of course, lead to the expansion of the money stock, which is illustrated in the third column.

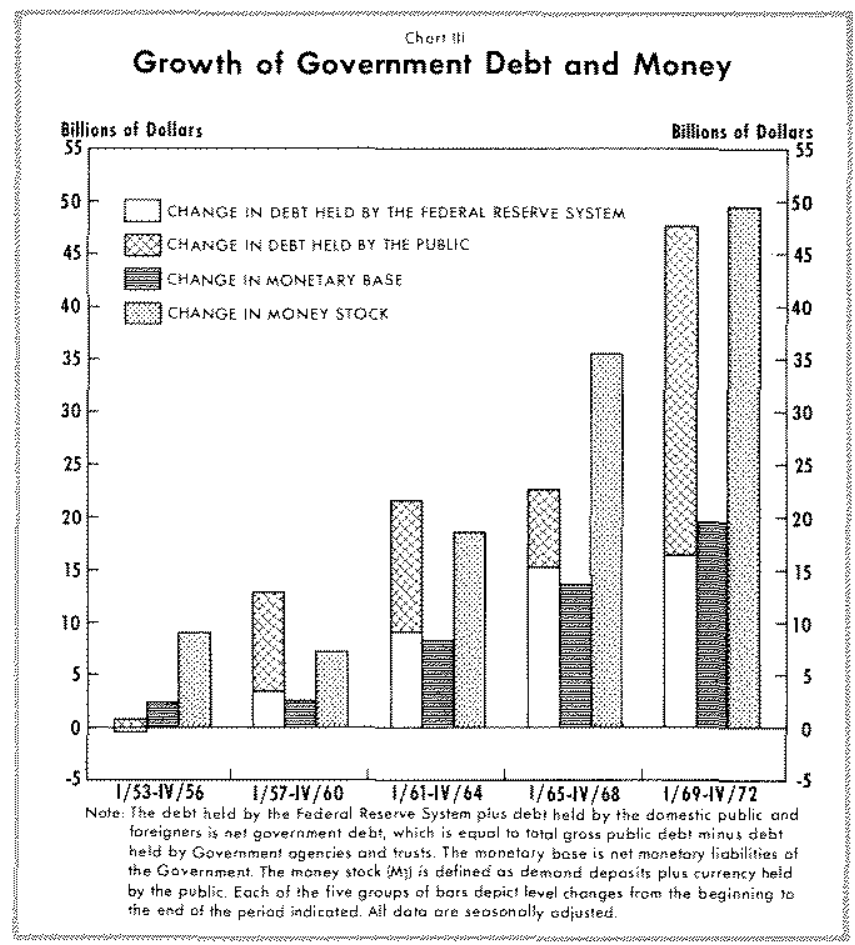

I doubt that monetization of debt has been a conscious act on the part of the Government or on the part of the Federal Reserve System. Rather, I believe the reason it has occurred lies in the relative visibility of the three methods of financing Government expenditures - taxes, borrowing from the public, and indirect debt monetization. Elements of our society have been continually demanding additional services from the Government, such as more defense, more social security, more medical security, and so forth. Since these services absorb resources which are limited, someone has to give up resources from other produc. tive uses.

When these additional services are paid for with increased taxes, the real resource cost is clearly visible to all taxpayers since they find their disposable income reduced. When they are financed by borrowing from the public, the effect is immediately felt by those competing for funds in capital markets and is visible in the form of higher interest rates. But in the case of debt monetization, the immediate and even the shortrun impact is neither an increase in taxes, nor an increase in interest rates. And yet, real resources still are being transferred from private to Government use. The ultimate effect of this method of financing Govemment expenditures is manifested in an increase in the price level - inflation - and this occurs only after a substantial lag. It is the lack of immediate visibility of the costs associated with this method of financing, I believe, that has contributed to the process of inflation. Once the inflation has been generated, a substantial period of time is required to reverse it, and unfortunately this can be accomplished only by incurring costs of lost output and higher unemployment.

Thus, over short periods of time it has appeared that debt monetization gives society something for nothing. And although this alternative may not have been chosen consciously and the actions which monetized the debt may not have been taken for that purpose, the excessive concern over market interest rates and the occurrence of large Government deficits led to this course of action.

I can find no benefits accruing to the whole of society from debt monetization, but the risks are very serious and can be expressed in one word - inflation. In the way that I have described above, to a considerable extent since the mid-1960s, deficit spending financed indirectly by Federal Reserve purchases of securities on the open market has meant an increase in money which has exceeded the growth in our output potential, and therefore has been inflationary.

Turning to another issue, it is my belief that shifting emphasis of monetary actions because of a presumed trade-off between inflation and unemployment has contributed to the rapid monetary expansion. The 
idea of a trade off between unemployment and inflation typically assumes that high rates of unemployment are associated with low inflation, and low rates of unemployment are associated with high rates of inflation. This view has led some analysts to argue that policy actions can assist the economy in achieving an acceptable combination of unemployment and inflation.

However, experience indicates that the unemployment-infation trade-off, if it exists at all, is purely a short-run phenomenon. Chart IV demonstrates that there exists no long-run relationship between the unemployment rate and the level of inflation. The only striking features $I$ find are that since 1952 the yearly average unemployment rate has clustered around its average ( 4.9 percent) for the whole period, and the rate of inflation, regardless of the level of the unemployment rate, has moved progressively higher since the mid - 1960s.

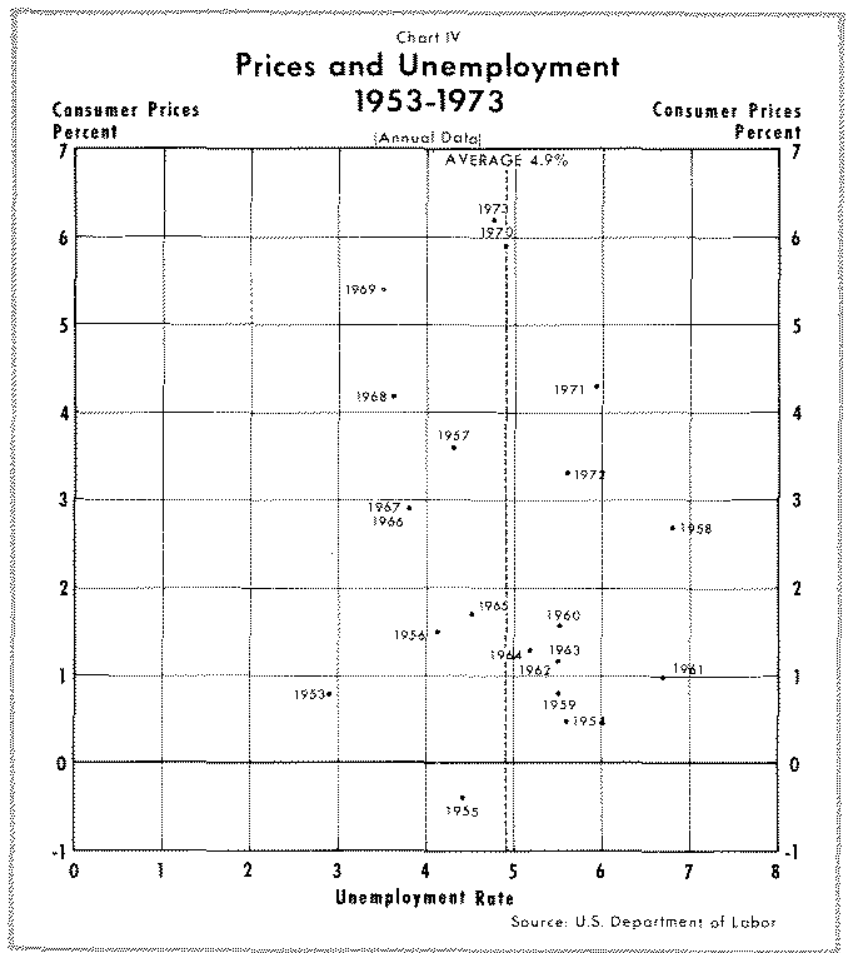

In the past, emphasis of monetary policy actions has, at various times, shifted between reducing inflation and reducing the unemployment rate, For example, according to the published policy Record, since the early-1960s (except 1966 and 1969) a primary goal was lower unemployment, and expansionary monetary policies were adopted to achieve it. In 1966 and 1969 emphasis was on achieving lower rates of inflation, and restrictive monetary policies were accordingly adopted. However, on balance the actions taken in the past decade resulted in periods of rapid monetary growth which were longer than those of slower growth, and the result was a rising average growth rate of the money stock. More recently the emphasis of the adopted policies again has been to reduce inflation, but the actions taken thus far have not resulted in a reduction in the average growth rate of the money supply.

It is my view that there will always be some normal rate of unemployment as new workers enter the labor market, as relative demands and supplies for labor services change, and as workers simply leave present jobs to find more rewarding ones elsewhere. Such a level is not necessarily desirable, but rather it is a level determined by the normal functioning of our product and labor markets, given existing institutional and social conditions.

Monetary actions cannot influence this normal level of memployment; other policies are necessary to attack that problem. As a matter of fact, monetary actions taken in an effort to reduce unemployment have contributed to increased inflationary pressures. Subsequent attempts to arrest inflation have temporarily fostered increased unemployment in addition to the normal amount consistent with existing labor market conditions.

My analysis of the unemployment-inflation trade-off leads me to conclude that it is non-existent, except possibly for very short intervals of time. Therefore, with relatively stable monetary growth over a long period, I believe it would be possible to have an essentially stable average level of prices, and this could be accomplished without accepting a permanently higher unemployment rate. The desire to reduce the average level of unemployment should be approached through programs which reduce or eliminate institutional rigidities and barriers to entry in labor markets, which provide job training, and which improve information regarding job availability.

In recent months a new proposal has been advanced which, if adopted, would most likely lead to further acceleration in the rate of monetary expansion, thereby adding to indlationary pressures. It has been suggested that it is appropriate for monetary and fiscal authorities to stimulate aggregate demand during periods when domestic production is curtailed by some special event, such as the oil boycott, or when foreign demand for a specific product, like wheat, increases suddenly. The argument is that the resulting price pressure from such non-recurring events is inevitable and that an expansionary aggregate demand program is required to protect employment in the case of a decrease in domestic production, and to 
protect consumer buying power in the case of an increase in foreign demand. Unfortunately, the probability of achieving either of these goals with stimulative monetary actions is very small and the costs in terms of accelerated inflation are certain.

The main point to keep in mind is that the forces that cause prices to rise in a specific market are very different from those which cause inflation - a persistent rise in the average price of all items traded in the economy. The prices of individual items rise and fall continuously, and an increase in a particular price, even if it is the price of an important budget item like food, is not necessarily an indication of general inflationary pressures. In the absence of additional monetary stimulus to aggregate demand, price increases in specific markets are a signal that either the demand or supply conditions, or both, have changed; not that total demand for all goods and services has increased. Such price increases serve a very useful function of allocating scarce resources according to consumer preferences.

An increase in foreign demand for American products is not inflationary per se. It represents a shift in the composition of demand for our output, but not an inflationary increase in aggregate demand. Inflation would occur if monetary actions were taken in order to accommodate the price pressure in individual commodity markets. In the case of some unforeseen event, such as a domestic crop failure or an embargo on imports of raw materials, the productive capacity of the economy is reduced. Most of the time the effect is temporary, but, as in the case of the oil embargo, the effect can be long-lasting. There is little that an increase in aggregate demand can do to stimulate more production in such a situation.

In my opinion, a monetary policy which results in an increased growth of the money stock has no role to play in accommodating the relative price effects of autonomous changes in demand or supply in specific markets. Such monetary actions would only raise the overall rate of inflation. Temporary gains in output and employment might be achieved, but the ultimate effect would be only on the rate of change of prices in general.

I now turn to my final topic - the contribution that monetary policy can make to reducing the rate of inflation and lowering market interest rates. My views on this topic should by now be very obvious; monetary actions can, and must, make a positive contribution. The interests of the whole economy would be best served if the trend growth rate of the money stock were to be gradually, but persistently, reduced from the high rates experienced in the recent past. I believe that, once we achieved and maintained a 2 to 3 percent rate of money growth, both the rate of inflation and the level of interest rates would ultimately decline to their levels of the early 1960 s.

I believe such a policy of gradual, rather than abrupt, reduction in the rate of monetary expansion from the high average rate so far in the $1970 \mathrm{~s}$, would not have severely adverse effects on the growth of output and employment. Such a gradual policy would probably mean, however, that the period of comm batting inflation and high interest rates would extend through the balance of the 1970s.

Some analysts believe that if the Federal Reserve sought to control the rate of growth of the money supply within a fairly narrow range, unacceptable short-run fluctuations in short-term interest rates would be generated. I do not believe that it is necessary for the Federal Reserve to intervene systematically in financial markets in order to maintain orderly conditions.

It seems to me that there are three basic parts to this argument regarding the desirability of actions to smooth short-run interest rate fluctuations. First, the argument assumes that Federal Reserve actions in the past have in fact reduced short-run fluctuations in short-term interest rates compared to what they otherwise would have been. As far as I am aware, there is no substantial body of empirical evidence supporting this claim. There is, however, a large and growing body of evidence suggesting that highly organized financial markets by themselves do not generate excessive and unwarranted short-run interest rate fluctuations.

Second, this argument assumes that by stabilizing short-term rates the System can, in the short-run, stabilize intermediate and long-term interest rates. Again, I am not aware of any empirical evidence in support of this proposition.

Third, this position assumes that short-run fluctuations in interest rates have a significant impact on the ultimate goals of stabilization policy - namely, price stability, a high level of employment, and economic growth. I know of no reason to believe that moderating short-run fluctuations in short-term interest rates has any significant stabilizing influence on prices, output, or employment. Even within the context of the well-known econometric forecasting models, stabilization of short-term interest rates has almost no stabilizing influence on prices, output, or employment. 
Some would oppose my recommended course of monetary policy on the grounds that it would not allow the Federal Reserve to perform its responsibility of a lender of last resort; so I want to make my views clear on this point. I believe it is possible that the failure of a major bank or other corporation can, at times, disrupt the smooth functioning of our financial markets. In my opinion, the Federal Reserve has an obligation to prevent the temporary problems of a major institution from affecting financial markets and perhaps even affecting the economy.

At the same time, however, I do not think that the System should subsidize inefficient management by making funds available at interest rates well below market rates, or be concerned about the losses that stockholders of a basically unsound institution might suffer. In the long run, such actions can only weaken, rather than strengthen, the financial system, as well as the business community at large.

Any temporary assistance to a basically sound institution should be unwound in a relatively short period of time. At the same time, the provision of funds through the Federal Reserve discount window should be matched by a sale of securities from the System's portfolio in order to prevent an expansion in the monetary base and the money stock.

Carrying out the monetary policy actions that I recommend could be greatly facilitated by complementary actions on the part of others. A balanced Government budget would eliminate much of the pressure on interest rates, thereby removing one cause of accelerating money growth in the past. Legislation removing impediments to the free functioning of our product, labor, and financial markets would allow these markets to adjust to monetary restraint more rapidly, and without the severe dislocations of the past.

It would also be helpful if all segments of our society would realize that rapid monetary growth, inflation, and high market interest rates go hand-inhand; that, once initiated, inflation cannot be eliminated without some temporary costs in terms of slower growth of output and employment; and that considerable time will be required to reduce substantially both the rate of inflation and the level of interest rates. Such realizations would tend to mitigate the short-run pressures that in the past have resulted in postponements of efforts to curb inflation. 